\title{
Okul Öncesi Dönem Çocuklarına Yönelik Dinleme Becerilerini Değerlendirme Ölçeğinin Geliştirilmesi
}

\author{
Yrd. Doç. Dr. Yeşim ÖZER ÖZKAN* \\ Gaziantep Üniversitesi, Gaziantep Eğitim Fakültesi, Eğitim Bilimleri Bölümü, \\ Eğitimde Ölçme ve Değerlendirme A.B.D., Gaziantep / Türkiye
}

\section{Arş. Gör. Lütfiye COŞKUN}

Kilis 7 Aralık Üniversitesi, Muallim Rıfat Eğitim Fakültesi, İlköğretim Bölümü, Okul Öncesi Öğretmenliği A.B.D., Kilis / Türkiye

\section{$\ddot{O} z$}

Bu çalışmada, okul öncesi dönem çocuklarının dinleme becerilerini değerlendirmek için ölçek geliştirilmesi amaçlanmıştır. Araştırmanın çalışma evrenini, Kilis ili merkezinde bağımsız anaokullarına devam eden okul öncesi dönem çocukları oluşturmuştur. Ölçeğin geçerlik ve güvenirlik çalışmaları, çalışma evreninin tamamına ulaşılarak, 240 çocuk üzerinde gerçekleştirilmiştir. Kapsam ve görünüş geçerliği için uzman görüşüne başvurulmuştur. Yapı geçerliği için Açımlayıcı Faktör Analizi (AFA) ve Doğrulayıcı Faktör Analizi (DFA) yapılmıştır. Yapılan AFA sonucunda, toplam varyansın \%70.07'sini açıklayan, bilişsel ve sosyal olmak üzere, iki faktörden

\footnotetext{
* Sorumlu Yazar. Tel: +903423172759 T-posta: yozer80@ gmail.com
}

(C) 2015 Kalem Eğitim ve Sağlık Hizmetleri Vakfi. Bütün Hakları Saklıdır. ～ISSN: 2146-5606 
oluşan bir yapı elde edilmiştir. AFA ile önerilen faktör modeli, DFA ile test edilmiştir. DFA sonucu elde edilen uyum indekslerinden RMSEA değeri 0.09 ve CFI değeri ise 0.98 olarak hesaplanmıştır. DFA sonuçları, iki faktörlü yapının yeterli uyuma sahip olduğunu göstermiştir. Geliştirilen ölçeğin iç tutarlılık güvenirliğine ilişkin hesaplanan Cronbach Alfa katsayısı 0.94 olarak elde edilmiştir. Ölçekteki maddelerin ayırt ediciliğini belirlemek amaciyla, madde toplam test korelâsyonu hesaplanmıştır. Madde analizinden elde edilen bulgular, ölçekte yer alan maddelerin tamamının yeterli ayırt edicilik düzeyinde olduğunu göstermiştir. Yapılan analizler sonucunda, “Okul Öncesi Dönem Çocuklarının Dinleme Becerilerini Değerlendirme Ölçeği”nin geçerli ve güvenilir olduğu kabul edilmiştir.

Anahtar Kelimeler: Dinleme becerisi; Okul öncesi eğitim; Ölçek geliştirme; Güvenirlik; Geçerlik.

\section{A Scale Development For Evaluating The Listening Skills of Preschool Period Children}

\section{Abstract}

It's aimed to develop a scale in order to evaluate the listening skills of preschool children in this study. The research group has been composed of pre-school children continuing independent kindergartens which are situated in Kilis city centre. In order to carry out the validity and reliability studies of the scale prepared with the aim of evaluating the listening skills of preschool period children, 240 children were taken into the research group. For the content and face validity of the scale, expert's opinion was asked. Exploratory Factor Analysis (EFA) and Confirmatory Factor Analysis (CFA) were implemented for construct validity. At the end of EFA, a form explaining the $70.07 \%$ of total variance, composed of two factors of cognitive and social has been obtained. Factor model offered with EFA was tested with CFA. RMSEA was calculated as 0.09 and CFI was calculated as 0.98. CFA results have shown that the form with two factors has sufficient fit-indexes. The calculated Cronbach $\alpha$ coefficient of internal consistency regarding the reliability of the scale was got as 0.94 . There has been given a place to item total correlation adjusted with the aim of determining distinctiveness of the items in the scale with $27 \%$ sub-super groups comparisons. The findings obtained from item analysis have shown that all 
items existing in the scale are distinctive. At the end of the analysis conducted, it's been accepted that "The Evaluation Scale of Preschool Period Children's Interception Skill" is valid and reliable.

Keywords: Listening skills; Preschool; Scale development; Reliability; Validity.

\section{Extended Summary}

\section{Purpose}

Listening ability of a child begins from prenatal age by listening heart of the child's mother. It is believed that the fetus is capable of hearing sensitivity after the fifth month in the womb. In that age fetus can hear inside sounds as well as adapting sounds coming from outside of the mother's body (Robinshaw, 2007). Studies show that listening skills of trained students improved more. An effective listening education starts from pre-school age. Teachers in pre-schools try to give listening ability to children by some activities. Therefore, improvement of listening ability is not a random process, carried out by a serious education (Özbay, 2005).

One of the basic language skills of listening skills, is very important in children's readiness to primary school and preliteracy. It is reported that listening comprehension is stated that support for later reading comprehension (Florit, Roch, Altoe'G and Levorato, 2009). Listening skills are also important in social success not only in the academic success of children. Language is a social tool. Therefore, listening has an significant importance in interpersonal relationships (Jalongo, 2010).

It is observed that, in designed studies to describe listening abi- 
lities, participants views were used (Coakley, Halone and Wolvin, 1996; Halone, Wolvin and Coakley, 1997; Halone and Pecchioni, 2001). It is seen that, in order to evaluate the listening skills of adults, scale development studies on those skills were performed (Cooper and Husband, 1993; Cooper, 1997; Cooper, Seibold and Suchner, 1997; Cooper and Buchanan, 2010; Imhof and Janusik, 2006).

Literature survey revealed that, there was no study to identify and develop the listening skills of preschoolers. It is seen that studies about listening skills mostly focused on training activities and programs for listening of elementary school students (Doğan, 2007, 2008, 2010; Y1lmaz, 2007). However, it is known that listening skills form the basis of other language skills and has an importance in readiness of children to school and preliteracy skills. In order to design education programs about those skills, describing of listening skills and determining listening skills of children must be performed. It's aimed to develop a scale in order to evaluate the listening skills of preschool children in this study.

\section{Method}

The research group has been composed of pre-school children continuing independent kindergartens which are situated in Kilis city centre. In order to carry out the validity and reliability studies of the scale prepared with the aim of evaluating the interception skills of preschool period children, 240 children were taken into the research group. 


\section{Results}

For the content and face validity of the scale, expert's opinion was asked. Exploratory Factor Analysis (EFA) and Confirmatory Factor Analysis (CFA) were implemented for construct validity. At the end of EFA, a form explaining the $70.07 \%$ of total variance, composed of two factors of cognitive and social has been obtained. Factor model offered with EFA was tested with CFA. RMSEA was calculated as 0.09 and CFI was calculated as 0.98 . CFA results have shown that the form with two factors has sufficient fit-indexes. The calculated Cronbach $\alpha$ coefficient of internal consistency regarding the reliability of the scale was got as 0.94 . There has been given a place to item total correlation adjusted with the aim of determining distinctiveness of the items in the scale with $27 \%$ sub-super groups comparisons. The findings obtained from item analysis have shown that item total correlation range between 0.52 and 0.88 and all of the items in the scale were discriminatory.

\section{Conclusion}

Listening ability of a child is the first ability of language skills that was learned and developed before speaking. This ability has a significant effect on the language ability of babies and children and starts with observing speech of their parents (Machado, 2010, p.242). Listening skills are also basis of the other language skills (Özbay, 2005, p.9). It is known that, in Turkey, there is no scale to evaluate listening skills of preschoolers. So, this scale development study in pre-school education is thought to be important in terms of contribution in this 
field.

In this research, the findings from statistical analyses of psychometric characteristics of "The Evaluation Scale of Preschool Period Children's Interception Skill" revealed that the scale can be used as a valid and reliable instrument to evaluate the listening skills of preschool children.

\section{Giriş}

Dinleme yeteneği, henüz doğum öncesi dönemde, çocuğun annesinin kalbini dinlemesiyle başlamaktadır. Genel olarak, fetüsün işitme konusunda yetenekli olduğuna ve işitme duyarlılığının ana rahminde beşinci aydan itibaren başladığına inanılmaktadır. $\mathrm{Bu}$ dönemde, çocuk anne vücudundaki seslerle birlikte, vücûdun dışındaki seslere de duyarlı olmaktadır (Robinshaw, 2007). Bu nedenle dinleme becerisi, öğrenilen ilk dil becerisi olup daha çocuk konuşmaya başlamadan gelişmektedir. Bebeklerin ve çocukların konuşan kişilerin söylediklerine dikkat etmesiyle gelişimine devam eden dinleme becerileri, dil gelişimi üzerinde oldukça etkilidir (Machado, 2010, s.242). Dolayısıyla, dinleme becerilerinin diğer dil becerilerinin de temelini oluşturduğu ifade edilebilir (Özbay, 2005, s.9).

Dinleme becerileri, bütün anlatılanlara rağmen, yıllardır önemsenmeyen ve unutulan bir dil san'atı olmuştur. Ancak, yanlış olan bu anlayışın gözden geçirilmesi ve yeniden yapılandırılması gerekmektedir (Janusik, 2002). Dinleme becerileri, pasif beceriler olarak algilansa da aktif düşünmeyi ve yorum yapmayı gerektirmektedir. Okul öncesi 
yıllar, çocukların hikâye duymak istedikleri, kişisel hikâyelerini tekrarladıkları ve ne işittiklerini hatırlama stratejileri geliştirmeye başlad1kları bir dönemdir (Visu-Petra, Cheie ve Benga, 2008, s.23). Dolayısıyla, dinleme becerileri şansa bırakılmamalı çocukların bu becerilerini geliştirmek için, iyi organize edilmiş programlar plânlanmalıdır (Machado, 2010, s.242). Bu programlar aracılığıyla, okul öncesi dönemde görevli öğretmenler, çocuklar için ses kaynaklı oyunlar planlayarak çocuklara dinleme becerilerini geliştirebilmeleri için birçok firsat sunabilirler.

Dinleme sürecinde program önemli bir değişken olup, kaliteli bir program çocukların dinleme becerilerine yönelik deneyimlerine katkı sağlayabilecektir (Jalongo, 2010). Bu sebeple, plânlanacak aktivitelerin çocukların dinleme deneyimlerine ilişkin olması ve çocukların repertuarlarını genişletmesi amaçlanmalıdır (Jones, 2007). Bu yolla, okul öncesi eğitim çağında etkili bir dinleme eğitimi alan çocuğun okuma, yazma, konuşma becerileri de gelişmektedir. Sonuç olarak dinleme; bilgi edinmenin, öğrenmenin, anlamanın, daha önce kazanılmış deneyimlerden yararlanmanın en önemli yollarından biri olarak ifade edilebilir (Calp, 2005).

Araştırmalar, dinlediğini anlama konusunda eğitilen öğrencilerin, dinleme becerisinin daha çok geliştiğini göstermektedir. Etkili bir dinleme eğitiminin temelleri ise, okul öncesinde atılabilir. Anaokullarında öğretmenler, birtakım uygulamalarla, çocuklara dinleme alışkanlığı vermeye çalışmaktadırlar. Dolayısıyla dinleme becerisinin geliştirilmesi, gelişigüzel bir süreçte değil; iyi plânlanmış bir eğitimle 
gerçekleştirilebilir (Özbay, 2005).

Plânlanmış bir eğitimle dinleme becerilerinin geliştirilmesinde en önemli paydaşlardan biri de öğretmenlerdir. Öncelikle, öğretmenlerin çocukların dinleme becerilerini destekleyebilmesi için, öğrenme ortamını uygun hale getirmesi gerekmektedir. Bunu gerçekleştirmek için öğretmenlerin konuşma hızlarını ayarlamaları, ses yüksekliklerini düzenlemeleri ve çocukların dikkatlerinin dağılmasına neden olan gürültüleri engellemeleri gerekmektedir. Çünkü bu faktörler çocukların dinleme kavrayışları üzerinde olumsuz etkiye sahiptir (Robinshaw, 2007; Swain, Harrington ve Friehe, 2004). Dinleme ortamını oluşturan ögelerin nitelikleri ve bu öğelerin çocukların dinleme durumları ile ilişkisinin incelendiği bir çalışmada, ortamın dinleme üzerinde etkili olduğu görülmüştür (Rubin, Flagg-William, Aquino-Russell ve Lushington, 2011). Bir başka çalışmada, öğretmenlere çocukların dinleme becerileri üzerine eğitim verildiğinde, bu öğretmenlerin sınıflarındaki çocuklarda dinleme becerilerin geliştiği sonucuna ulaşılmıştır (Crosskey ve Vance, 2011).

Temel dil becerilerinden biri olan dinleme becerisi, çocukların ilkokula hazırlık ve okuma yazmaya hazırlık konularında da önemli görülmektedir. Diğer bir anlatımla, dinleme becerilerinin daha sonraki okuma yeterliliklerine destek olduğu belirtilmektedir (Florit, Roch, Altoe 'G ve Levorato, 2009). Yapılan çalışmalarda da, dinleme becerileri ile metni hatırlama arasında ilişki kurulduğu ve okuma yazma yeterliliği üzerine vurgu yapıldığg 1 görülmektedir (Florit, Roch, Altoe`G ve Levorato, 2011; Florit ve diğer., 2009). Alanyazında, çocukların 
dinleme becerisi ile okuma yeterliliği ve ögrenme becerisi arasında ilişki olduğunu ortaya koyan çalışmalar da (Lamm, Share, Shatil ve Epstein, 1999; Smith, 2006) mevcuttur. Ayrıca, erken çocuklukta edinilen bütün dinleme deneyimlerinin, yazı merhaleleri için temel oluşturduğu belirtilmektedir (Jalongo, 2010).

Dinleme becerileri çocukların yalnız akademik başarılarında değil, sosyal başarılarında da önemli bir yere sâhiptir. Dil sosyal bir araçtır ve kişilerarası ilişkilerde önemli görülmektedir (Jalongo, 2010). Spitzberg (1988)'e göre dinleme, iletişim davranışlarının uygun ve etkili olma koşulunu gerektirmektedir (akt; Cooper ve Buchanan, 2010). Meselâ Estrem (2005) yaptığı çalışmada, fiziksel şiddetin, daha az alıcı dil becerilerine sâhip olan erkek çocuklarda, diğer erkek çocuklara oranla daha fazla olduğunu görmüş, okul öncesi çocuklarda görülen davranışsal problemlerin, sık sık zayıf alıcı dil becerileri nedeniyle meydana geldiğini belirtmiştir.

Okuma yazma sürecine başlamadan önce, okul öncesi dönem çocuklarının dinleme becerilerindeki farklılıkların analiz edilmesi gerekmektedir (Florit ve diğer., 2009). Çok dikkatli olan ve normal işiten çocukların bile tam olarak dinleme becerilerinin gelişmemiş olabileceği düşünüldüğünde, öğretmenlerin çocukların dinleme becerilerini desteklemeye yönelik etkinlikler oluşturabilmesi için, bu becerilerin ne olduğunu bilmesi gerekmektedir (Robinshaw, 2007). Çocukların bu becerilerinin değerlendirilmesi, diğer yaş gruplarına göre daha zordur; çünkü çocuklar yaşları gereği, sorulara cevap verememe ve dikkatin çabuk dağılması gibi sıkıntılar yaşarlar. Bütün bunlara rağmen, ço- 
cukların dinleme süreçlerini anlamamıza katkı sağlayacak çalışmalarının ortaya konulması önemlidir (Jalongo, 2010).

Dinleme becerilerini tanımlayabilmek amacıyla oluşturulan çalışmalarda, katılımcı görüşlerinden faydalanıldı̆̆ (Coakley, Halone ve Wolvin, 1996; Halone, Wolvin ve Coakley, 1997; Halone ve Pecchioni 2001). Ayrıca, yetişkinlerin dinleme becerilerini değerlendirebilmek amaciyla, bu becerilere yönelik ölçek geliştirme çalışmalarının da (Cooper ve Husband, 1993; Cooper, 1997; Cooper, Seibold ve Suchner, 1997; Cooper ve Buchanan, 2010; Imhof ve Janusik, 2006) yapıldığı bilinmektedir.

Alanyazın incelendiğinde, okul öncesi dönem çocuklarının dinleme becerilerini belirlemeye ve geliştirmeye yönelik çalışmaların yetersizliği, dinleme becerilerine yönelik yapılan sınırlı çalışmalarda ise, ilköğretim öğrencilerine yönelik dinleme eğitimi etkinlikleri ve programları üzerinde durulduğu (Doğan 2007, 2008, 2010; Y1lmaz, 2007) görülmektedir. Dinleme becerilerinin, bir kez daha belirtmek gerekirse, diğer dil becerilerinin temelini oluşturduğu düşünüldüğünde, bu becerilerin çocukların ilkokula ve okuma yazmaya hazırlığı konusunda ne kadar önemli olduğu ve eğitimle desteklenmesi gerektiği gerçeği ortaya çıkmaktadır. Dolayısıyla, bu becerilere yönelik eğitim programlarının oluşturulması için, dinleme becerilerinin tanımlanması ve çocukların mevcut dinleme becerilerinin değerlendirmesi gerekmektedir.

Türkiye'de okul öncesi dönem çocuklarının dinleme becerilerini 
değerlendirmeye yönelik bir ölçeğin olmadığı gerçeğinden hareketle, bu araştırma kapsamında ele alınacak ölçek geliştirme çalışmasının, okul öncesi eğitim alanındaki mevcut eksikliği giderebileceği ve alana katk1 sağlayabileceği düşünülmektedir. Bu nedenle araştırmada, okul öncesi dönem çocukları için dinleme becerilerinin belirlenmesinde ve değerlendirilmesinde kullanılabilecek geçerliği ve güvenirliği yüksek bir ölçme aracının geliştirilmesi amaçlanmaktadır.

\section{Yöntem}

\section{Araştırma Modeli}

Okul öncesi dönem çocuklarının dinleme becerilerini değerlendirmek için bir ölçek geliştirilmesinin amaçlandığı bu araştırma, genel tarama modelindedir.

\section{Çalışma Grubu}

Araştırmanın çalışma grubunu, Kilis il merkezinde Millî Eğitim Bakanlığına (MEB) bağlı, Osman Baysal Anaokulu, Atilla Kâmil Kudeyt Anaokulu, TOKİ Anaokulu, Şemsi Ahmet Ünlükahraman Anaokulu'na devam eden, 5 yaş grubu 240 çocuk oluşturmaktadır. Çalışma grubunda $123(\% 51)$ kız ve 117 (\%49) erkek öğrenci yer almiştır.

\section{Veri Toplama Araçları}

Çalışma kapsamında araştırmacılar tarafından geliştirilen veri toplama aracı, iki bölümden oluşmaktadır. Birinci bölümde, çocukların yaşı ve cinsiyetine ilişkin demografik sorular yer almaktadır. İkinci bölüm ise, çocukların dinleme becerilerini değerlendirmek için gelişti- 
rilen ölçek maddelerinden oluşmaktadır. Araştırma amacı doğrultusunda hazırlanan ölçeğin geliştirilme merhalesinde yapılan işlemler, ölçeğin puanlanması ve değerlendirilmesi için gerekli bilgiler, aşağıda betimlenerek sunulmuştur.

Dinleme Becerileri Ölçeği (DBÖ): Ölçeğe ilişkin madde yazım merhalesinde, öncelikle dinleme becerilerine yönelik alanyazın taraması yapılmıştır. Dinleme becerilerini belirlemeye ve değerlendirmeye yönelik oluşturulan çalışmalardan ve MEB okul öncesi eğitim programlarından faydalanılarak, çocukların dinleme becerilerini ölçebileceği düşünülen maddeler yazılmıştır (MEB, 2006, 2012; Machado, 2010; Jalongo, 2010; Imhof ve Janusik, 2006; Mickelson ve Welch, 2012). Konuşanın mesajına odaklanma, konuşmacının söylediği şeyi tekrarlama, konuşanın yüzüne doğru bakma, söz kesmeme ve söylenen şey hakkında düşünüyor gibi görünme; dinleme becerisine âit özelliklerdir.

Çocuğun etkili bir dinleme yapabilmesi için gereken dinleme sürecinin; uyarıcılara yanıt verme, uyarıcıları organize etme ve ifadeyi anlama olmak üzere, üç merhaleden meydana geldiği belirtilmektedir (Machado, 2010). Bu süreçler ve boyutlar dikkate alınarak, çocukların dinleme becerilerine yönelik 39 ifadeyi içeren, madde havuzu oluşturulmuştur. Ayrıca, maddelerin oluşturulmasında, MEB okul öncesi programında yer alan dinleme kazanımlarından, alanyazındaki çalışmalardan, uzman görüşlerinden ve hedef kitle olan okul öncesi öğretmenlerinin görüşlerinden yararlanılmıştır. Maddeler dikkat, hatırlama, yeniden anlatma, cevap verme ve uyum sergileme gibi davranışları kapsamaktadır. 
Madde havuzu, uzman görüşlerine sunulmak amacıyla taslak bir forma dönüştürülmüştür. Taslak formun dinleme becerisi maddelerinin ilgili değişkeni ölçüp ölçmediği, ilgili madde türüne uygun olup olmadığı, yazım dilinin dil bilgisi açısından uygunluğu, anlaşılabilirliği, yanlılık taşıyıp taşımadığı, okunabilirliği ve yazım dilinin hedef kitleye uygunluğu açısından değerlendirilmesi için, uzman görüşleri alınmıştır. Uzmanlardan alınan görüşler doğrultusunda, ölçeğin amacına uygun olmayan ve dil açısından hatalı olduğu düşünülen maddeler üzerinde düzeltmeler yapılmış olup iki madde taslak formdan çıkarılmıştır.

Uygulamaya hazır hâle gelen ölçeğin; örnek bir gerçek hedef kitle üzerinde uygulamasının yapılmasının, maddelerin okunabilirliği-anlaşılabilirliği, cevaplayıcılar tarafindan anlaşılmayan yerlerin belirlenmesi, yanlış yerlerin saptanması, ortalama cevaplama süresinin belirlenmesi vb. açısından yararı bulunmaktadır (Erkuş, 2012). Bu nedenle, 37 maddeden oluşan taslak formun ön uygulama amaciyla, küçük bir grup üzerinde uygulaması yapılmıştır. Bu uygulama için, öğretmenden, 10 öğrencisini gözlemleyerek formları doldurmaları istenmiştir. Öğretmenden formları doldurma sırasında yaşadıkları güçlükler öğrenilmiş, ortalama her öğrenci için doldurma süreleri tespit edilmiştir. Ön deneme uygulamasından sonra ölçek, daha geniş bir örneklem üzerinde esas uygulamanın yapılması amacıyla, öğretmenden gelen geri bildirim doğrultusunda ifadelerde düzenlemeler yapılarak son şekli verilmiştir.

Ölçek “(1) Hiçbir zaman, (2) Ara sıra, (3) Çoğunlukla, (4) Her zaman" şeklinde 4'lü likert tipinde yapılandırılmıştır. Çocukların öl- 
çekten aldıkları puanlara ilişkin beceri düzeylerinin belirlenmesi amacıyla, ölçekte yer alan maddeler, "Her zaman"dan "Hiçbir zaman"a doğru 4'ten l'e sayısal değerler verilerek puanlanmıştır. Ölçekten alınan yüksek puanlar çocukların dinleme becerisinin yüksek, düşük puanlar ise, bu becerinin düşük düzeyde olduğunu göstermektedir.

\section{Verilerin Analizi}

Ölçeğin yapı geçerliği, Açımlayıcı Faktör Analizi (AFA) ve Doğrulayıc1 Faktör Analizi (DFA) kullanılarak incelenmiştir. Yapı geçerliği, testin soyut bir olguyu (kavramı, boyutu vb.) ne derece doğru ölçebildiğini gösterir. (Öner, 1997, s.19). AFA, birbiriyle ilişkili çok sayıda değişkeni bir araya getirerek az sayıda kavramsal olarak anlamlı yeni değişkenler (faktörler, boyutlar) bulmayı, keşfetmeyi amaçlayan çok değişkenli bir istatistiktir (Büyüköztürk, 2011, s.123). DFA ise, ölçek geliştirme sürecinin ilk merhalelerinde, son derece etkilidir (Şimşek, 2007, s.5). Madde geçerliğine ilişkin kanıtlar ise, madde toplam test korelasyonları hesaplanarak elde edilmiştir. Madde geçerliğine ilişkin değerler, test maddelerine verilen cevap ile ölçüt olarak alınan bir grubun performansı arasındaki korelasyonu bulma esasına dayanmaktadır (Özgüven, 2014).

Dinleme becerileri ölçeğinin iç tutarlılık anlamında güvenirliğini belirlemek amacıyla, Cronbach Alfa katsayısı hesaplanmıştır. Güvenirlik indeksi 0.00 ile 1.00 arasında olup; bu değer 0'a yaklaştıkça güvenirlik düşer, 1'e yaklaştıkça yükselir (Baykul, 2000, s.143). Diğer bir anlatımla, elde edilen yüksek değerler (1'e yakın değerler), güvenirliğin yüksek olduğunun göstergesidir. Ölçme amacına göre değiş- 
mekle birlikte, önerilen en düşük Cronbach Alfa değeri 0.70'dir (Şeker ve Gençdoğan, 2006).

\section{Bulgular}

$\mathrm{Bu}$ bölümde; okul öncesi dönem çocukları için geliştirilen dinleme becerileri ölçeğine ilişkin, geçerlik ve güvenirlik kanıtlarına yer verilmiştir. Bu doğrultuda öncelikle ölçeğin kapsam geçerliğine ilişkin bulgular; ardından ölçeğin yapı geçerliğine ilişkin AFA ve DFA bulguları sunulmuştur. Madde geçerliğine ilişkin kanıtlar ise, madde toplam test korelasyonları hesaplanarak elde edilmiştir. İkinci merhalede, geçerlik kanıtları elde edilen 30 maddenin güvenirliğine ilişkin Cronbach Alfa iç tutarlık katsayısı verilmiştir.

\section{Dinleme Becerisi Ölçeğinin Geçerliğine İlişkin Bulgular}

Dinleme becerileri ölçeğinin içerik-kapsam geçerliği, uzman görüşü ile belirlenmiştir. 39 maddelik ölçek, üniversitelerin "Okul Öncesi Öğretmenliği”, “Ölçme ve Değerlendirme” ve “Türkçe Öğretmenliği’” bölümlerinden, toplam 7 uzmana sunulmuştur. İçerik geçerliği hakkındaki kanıtlar istatistiksel olmayıp uzman kanısına dayanırlar ve bu yönüyle özneldirler (Balcı, 2006; Tavşancıl, 2002). Kapsam geçerliğini sağlamak için hazırlanmış olan ölçme aracı, uzman kişilere inceletilir ve uzmanların görüşleri doğrultusunda ölçme aracı, gözden geçirilerek hazırlanır (Özgüven, 2014). Bu amaçla, "Uzman Değerlendirme Formu” hazırlanmıştır. Uzmanlardan, ölçekte yer alan her bir madde ile ilgili olarak, "uygun", "kısmen uygun" ya da "uygun değil” seçeneklerinden birini işaretlemeleri istenmiştir. Ayrıca, ölçeğin 
amacına uygun bulmadıkları veya dil açısından hatalı olduğunu düşündükleri maddelerin üzerinde düzeltme yapmaları ve varsa konuya ilişkin yeni madde önerilerini yazmaları istenmiştir. Madde havuzunun gönderildiği yedi uzmanın üçünden görüş alınamamış olup dördünden görüş alınarak uzmanların uygun bulduğu maddeler alınmış ve gerekli değişiklikler yapılmıştır.

Kapsam geçerliğinin ardından, ölçeğin yapı geçerliğini belirlemek amacıyla, faktör analizi yapılmıştır. Faktör analizinden önce, verilerin analiz için uygun olup olmadığı, KMO (Kaiser-Meyer-Olkin) katsayısı ve Barlett küresellik testi ile incelenmiştir. Büyüköztürk (2011), KMO'nun 0.60'dan yüksek, Barlett küresellik testinin ise anlamlı çıkmasının, verilerin faktör analizi için uygunluğunun bir göstergesi olduğunu belirtmektedir. Ayrıca KMO katsayısının 1'e yaklaştıkça verilerin analize daha uygun olduğu, 1 olmasında ise mükemmel bir uyum olduğu söylenebilir (Kan, 2007, s.39). Yapılan analiz sonucunda, KMO değeri 0.96 olarak bulunmuştur. Barlett küresellik testi ise anlamlidir $(X=8365.039 ; p<0.01)$.

Ölçeğin AFA ile çözümlemesine ilişkin sonuçlara göre, Varimax döndürme yöntemi kullanılarak yapılan işlem sonucunda, öz değerleri 1 den büyük iki faktör elde edilmiştir. Bu iki faktörün toplam varyansın \%70.70'ini açıkladığı görülmektedir. Bu durum, AFA sonucu elde edilen Şekil 1'deki özdeğer grafiğinde de sunulmuştur. 


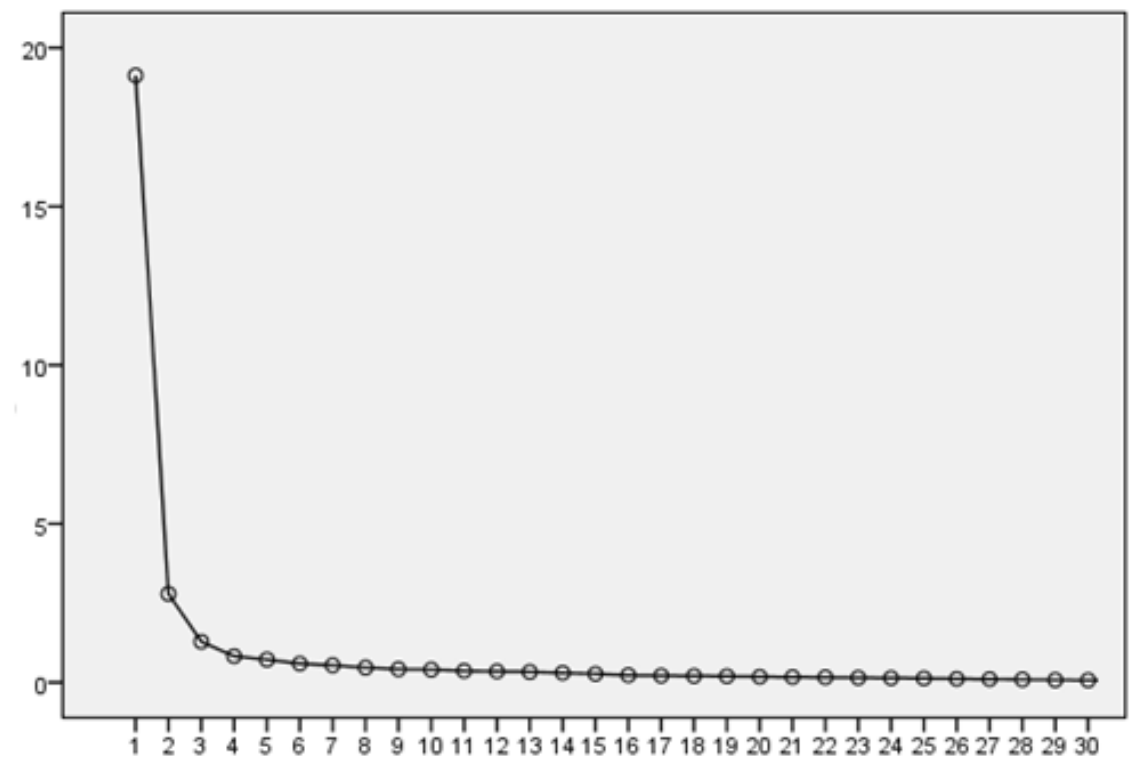

Şekil 1. Dinleme Becerileri Ölçeğine İlişkin Özdeğer Grafiği

Şekil 1'de görüldüğü gibi, ikinci faktörlere âit özdeğerden sonra üçüncü faktöre âit özdeğerde önemli bir düşüş olduğu; diğer faktörlerde ise, grafiğin yatay bir şekil aldığı ve özdeğerlerin birbirine çok yakın olduğu belirlenmiştir. Buna göre, ölçeğin iki faktörlü bir yapıya sâhip olduğu söylenebilir.

Faktörleri ilk elde edilen şekli ile yorumlamak zordur. Bunun sebebi, faktör elde ederken, aralarında yüksek ilişki olan değişkenlerin farklı faktörler altında yer alabilmeleri ve bunun hesaplamada göz ard1 edilmesidir. Tatlıdil (2002), elde edilen ilk faktörlerin döndürülmesi ile, daha iyi yorumlanabilecek basit yapılara ulaşılabileceğini belirtmiştir. $\mathrm{Bu}$ noktadan hareketle, verilere Varimaks döndürme yöntemi kullan1larak, testin faktör yapısı ortaya çıkarılmış ve Tablo 1'deki sonuçlara ulaşılmıştır. 
AFA sonucunda, 37 maddeden oluşan ölçekten; ölçeğin yapısına uymayan ya da birden fazla faktöre yük veren yedi madde $(10,13,14$, 18, 20, 25, 29) ölçekten çıkarılmıştır. Geriye kalan 30 madde, özdeğeri 1 'in üzerinde olan iki faktörlü bir yap1 oluşturmuştur. Bu faktörler, özyeterlik değişkenine ait varyansın \%70.70'sini açıklamaktadır. Maddeler atıldıktan sonra, ölçeğe ilişkin faktör yükleri ve ayırtedicilik değerleri, Tablo 1'de verilmiştir.

Tablo 1. Dinleme Becerilerini Değerlendirme Ölçeğine İlişkin Faktör Yükleri ve Ayırtedicilik Değerleri

\begin{tabular}{llccc}
\hline \multicolumn{1}{c}{ Maddeler } & r & $\begin{array}{c}\text { Faktör } \\
\mathbf{1}\end{array}$ & $\begin{array}{c}\text { Faktör } \\
\mathbf{2}\end{array}$ \\
\hline 1 & Dinlerken ve konuşurken göz teması kurar. & 0.68 & 0.679 \\
\hline 2 & Göz temasını sürdürür. & 0.70 & 0.721 \\
\hline 3 & Dinleyicinin söylediklerini vücut hareketleriyle tasdik eder. & 0.67 & 0.611 \\
\hline 4 & Konuşmacının sözünü kesmeden sabır ve saygıyla dinler. & 0.53 & 0.844 \\
\hline 5 & Başkalarını rahatsız etmeden dinler. & 0.58 & 0.839 \\
\hline 6 & Dinlenenle ilgili soru sormak, görüş bildirmek için sırasını bekler. & 0.62 & & 0.834 \\
\hline 7 & Söz almak için parmak kaldırır. & 0.59 & & 0.780 \\
\hline 8 & Sözel yönergeleri yerine getirir. & 0.65 & & 0.763 \\
\hline 9 & Sohbete katılmada isteklidir. & 0.65 & & 0.573 \\
\hline 10 & İlk kez karşışlaşı̆ı yeni sözcükleri fark eder. & 0.80 & 0.790 & \\
\hline 11 & Bilmediği sözcüklerin anlamını sorar. & 0.83 & 0.843 & \\
\hline 12 & Akışa uygun olmayan cümleyi ya da kelimeyi fark eder. & 0.84 & 0.823 & \\
\hline 13 & Ortamdaki gürültüden rahatsı olur & 0.66 & 0.579 & \\
\hline 14 & Dikkat edilmesi gereken nesne durum ve olaya odaklanır. & 0.82 & 0.703 & \\
\hline 15 & Dikkatini çeken nesne durum olaya yönelik sorular sorar. & 0.82 & 0.786 & \\
\hline 16 & Şiir öykü ve tekerlemedeki uyağı fark eder. & 0.72 & 0.706 & \\
\hline 17 & Uyaklı kelimeleri tekrarlar. & 0.72 & 0.658 & \\
\hline 18 & Dinlediklerine ilişkin sorular sorar. & 0.82 & 0.839 & \\
\hline 19 & İpuçlarından hareketle dinlediklerine yönelik tahminlerde bulunur. & 0.87 & 0.858 & \\
\hline 20 & Anlamadığı durumlarda yetişkinden anlatılanı tekrar etmesini ister. & 0.87 & 0.856 & \\
\hline 21 & Dinledikleri hakkında yorum yapar. & 0.80 & 0.785 & \\
\hline 22 & Dinledikleri ile ilgili sorulara cevap verir. & 0.82 & 0.773 & \\
\hline 23 & Dinlediklerini bir süre sonra yeniden anlatır. & 0.88 & 0.840 & \\
\hline 24 & Dinlediklerini oluş sırasına göre özetler. & 0.88 & 0.854 & \\
\hline 25 & Dikkatini çeken nesne durum olayı ayrıntılarıyla açıklar. & 0.88 & 0.865 & \\
\hline 26 & Dinlediklerini özetler. & 0.85 & 0.795 & \\
\hline 27 & Dinlediklerini resim, müzik, drama, şiir, öykü gibi yollarla sergiler. & 0.84 & 0.809 & \\
\hline & & & \\
\hline
\end{tabular}




\begin{tabular}{llrrr}
\hline 28 & Dinlediklerinde ortaya konan sorunlara farklı çözümler üretir. & 0.86 & 0.857 & \\
\hline 29 & Dinlediklerine deneyimlerinden örnekler vererek yaşantısılla ilişkilendirir. & 0.80 & 0.807 & \\
\hline 30 & Dinlediği metne farklı başlıklar bulur. & 0.75 & 0.748 & \\
\hline Özdeğer & & & 23.95 \\
\hline Toplam ölçek için açıklanan varyans oranı (\%) & & 70.7 \\
\hline Tüm ölçek için güvenirlik katsayısı Cronbach $\alpha$ & 0.94 \\
\hline
\end{tabular}

Tablo 1 incelendiğinde, ölçeği oluşturan maddelere ilişkin faktör yüklerinin, 0.57 ile 0.86 arasında değiştiği görülmektedir. Madde toplam test korelasyonları, test maddelerinden alınan puanlar ile testin toplam puanı arasındaki ilişkiyi açıklar. Madde toplam test korelasyonunun pozitif ve yüksek olması, maddelerin benzer davranışları örneklediğini ve testin iç tutarlığının yüksek olduğunu gösterir. Genel olarak, madde toplam test korelasyonu 0.30 ve daha yüksek olan maddelerin, ölçülen özelliğe sâhip olan bireyler ile sâhip olmayan bireyleri iyi derecede ayırt ettiği, $0.20-0.30$ arasında kalan maddelerin, zorunlu görülmesi durumunda teste alınabileceği veya maddenin düzeltilmesi gerektiği, 0.20 'den daha düşük maddelerin ise, teste alınmaması gerektiği söylenebilir (Büyüköztürk, 2011, s.171). Madde geçerliğine kanıt olarak hesaplanan madde toplam test korelasyonlar1nın, 0.52 ile 0.88 arasında değişstiği belirlenmiştir.

Maddelerin faktörlerde aldıkları yük değerleri incelendiğinde, 30 maddeden 21'inin en yüksek yük değerini birinci faktörde, 9'unun ise ikinci faktörde aldığ 1 görülmektedir. Faktörleri isimlendirmek amacıyla, ilgili alanyazın taramalarından yararlanılmıştır. Birinci faktörde uyum ve iletişim ile ilgili maddeler yer aldığı için, bu boyut "bilişsel"; ikinci faktörde ise dikkat, hatırlama, yeniden anlatma gibi davranışlarla ilgili maddeler yer aldığı için, bu boyut "sosyal" olarak isimlendiril- 
miştir.

AFA sonucunda elde edilen 30 madde ve iki faktörden oluşan yapının doğrulanıp doğrulanmadığını test etmek için, DFA uygulanmıştır. Model 0.05 anlamlılık düzeyinde, Maximum Likelihood yöntemi kullanılarak test edilmiştir. İlk merhalede model için elde edilen uyum indeksleri incelenmiştir.

Model uygunluğunun değerlendirilmesinde kullanılan, birbirinden farklı uyum iyiliği indeksleri ve bu indekslerin modelin kabul edilip edilmeyeceğine ilişkin, sınır değerleri vardır. Bunlar, Ki-Kare Uyum İyilik Testi (Chi-square Goodness-of-Fit Tests), Genel Model Uyumunun Tanımlayıcı Ölçümleri (Descriptive Measures of Overall Model Fit) ve Model Karşılaştırmasına Dayalı Tanımlayıcı Ölçümler (Descriptive Measures Based on Model Comparisons) olmak üzere üç grupta toplanabilirler (Schermelleh-Engel ve Moosbrugger, 2003).

$\mathrm{Bu}$ çalışmada, modelin yeterliğini ortaya koymak amacıyla incelenen bazı uyum değerlerinin, (NFI, NNFI, CFI ve SRMR) kabul edilebilir sınırlar içinde yer aldığı görülürken, bazı değerlerin $\left(X^{2} / \mathrm{sd}\right.$, RMSEA ve GFI) kabul edilebilir sınırlar içinde yer almadığı görülmektedir. DFA'da, uyum indekslerinin kabul düzeylerini karşılamaması durumunda, analiz sonucunda ortaya koyulan modifikasyon önerilerinin incelenmesi, yarar sağlamaktadır (Çokluk, Şekercioğlu ve Büyüköztürk, 2010). Bu nedenle, modifikasyon önerileri incelenmiş ve model üzerinde gerçekleştirilecek dört 
modifikasyon ile, ölçme modelinde uyum değerlerinin iyileştirilebileceği belirlenmiştir.

Modifikasyon önerilerine göre, M1 (Dinlerken ve konuşurken göz teması kurar) ile M2 (Göz temasını sürdürür); M15 (İlk kez karş1laştı̆̆1 yeni sözcükleri fark eder) ile M16 (Bilmediği sözcüklerin anlamını sorar); M23 (Şiir, öykü ve tekerlemedeki uyağı fark eder) ile M24 (Uyaklı kelimeleri tekrarlar); M30 (Dinledikleri hakkında yorum yapar) ile M31 (Dinledikleri ile ilgili sorulara cevap verir) arasına eklenecek hata kovaryansının, Ki-Kare üzerinde azalmaya yol açacağ gözlenmiştir.

Söz konusu maddeler incelendiğinde, içerik bakımından da benzer oldukları, benzer durumları yansıttıkları görülmüştür. Söz konusu maddeler arasına hata kovaryansları eklenerek ölçme modeli yeniden test edilmiştir. Yeniden test edilerek elde edilen uyum indekslerine ilişkin kabul edilebilir ve iyi uyum değerleri (Schermelleh-Engel ve Moosbrugger, 2003) ile birlikte ölçekten elde edilen değerler, Tablo 2'de sunulmuştur.

Tablo 2'de, modifikasyon sonucunda yeniden test edilerek elde edilen modelin, 0.05 anlamlılık düzeyinde mânidâr olduğu $(p \leq 0.05)$ görülmüştür. Model uyum indeksleri değerlendirildiğinde Ki-Kare değerinin anlamlı çıktığı görülmektedir. Ki-Kare değeri genelde anlamlı çıkmaktadır, çünkü bu değer örneklem büyüklüğüne oldukça duyarlıdır (Şimşek, 2007). Örneklem büyüklüğü arttıkça Ki-Kare değeri neredeyse her zaman anlamlı çıkar (Kline, 2005). 
Tablo 2. Uyum İndeksleri ve Ölçek Değerleri

\begin{tabular}{lccc}
\hline $\begin{array}{l}\text { Uyum } \\
\text { İndeksleri }\end{array}$ & İyi Uyum & Kabul Edilebilir Uyum & $\begin{array}{c}\text { Ölçek } \\
\text { Değerleri }\end{array}$ \\
\hline$x^{2} / d f$ & $0 \leq x^{2} / d f \leq 2$ & $2 \leq x^{2} / d f \leq 3$ & 3.02 \\
$\mathrm{p}$ değeri & $0.05<\mathrm{p} \leq 1.00$ & $0.01 \leq \mathrm{p} \leq 0.05$ & 0.00 \\
\hline RMSEA & $0 \leq R M S E A \leq 0.05$ & $0.05 \leq R M S E A \leq 0.10$ & 0.09 \\
SRMR & $0 \leq S R M R \leq 0.05$ & $0.05 \leq S R M R \leq 0.10$ & 0.08 \\
\hline NFI & $0.95 \leq \mathrm{NFI} \leq 1.00$ & $0.90 \leq \mathrm{NFI} \leq 0.95$ & 0.97 \\
$\mathrm{NNFI}$ & $0.97 \leq \mathrm{NNFI} \leq 1.00$ & $0.95 \leq \mathrm{NNFI} \leq 0.97$ & 0.98 \\
$\mathrm{CFI}$ & $0.95 \leq \mathrm{CFI} \leq 1.00$ & $0.90 \leq \mathrm{CFI} \leq 0.95$ & 0.98 \\
GFI & $0.95 \leq G F I \leq 1.00$ & $0.90 \leq G F I \leq 0.95$ & 0.75 \\
\hline
\end{tabular}

Ki kare tek başına değerlendirilen bir istatistik olmayıp Ki-Kare serbestlik derecesi ile oranlanarak değerlendirmeye alınması daha uygun görülmektedir (Çokluk, Şekercioğlu ve Büyüköztürk, 2010). Çalışmada elde edilen ki kare/serbestlik derecesi değeri (3.02), Schermelleh-Engel ve Moosbrugger (2003)'e göre kabul edilebilir, Sümer (2000)'e göre 5'in altında olmasından dolayı, orta uyuma karşılık gelmektedir.

RMSEA değerinin 0.09 olması, kabul edilebilir bir uyumu göstermektedir. NFI değerinin 0.97 ve CFI değerinin 0.98 olması modelin iyi bir uyum gösterdiğini belirtmektedir. Uyum indekslerinden sadece GFI değeri, iyi uyum göstermemiştir. DFA sonucunda elde edilen iki boyutlu modele ilişkin faktör yükleri, Şekil 2'de yer almaktadır. 


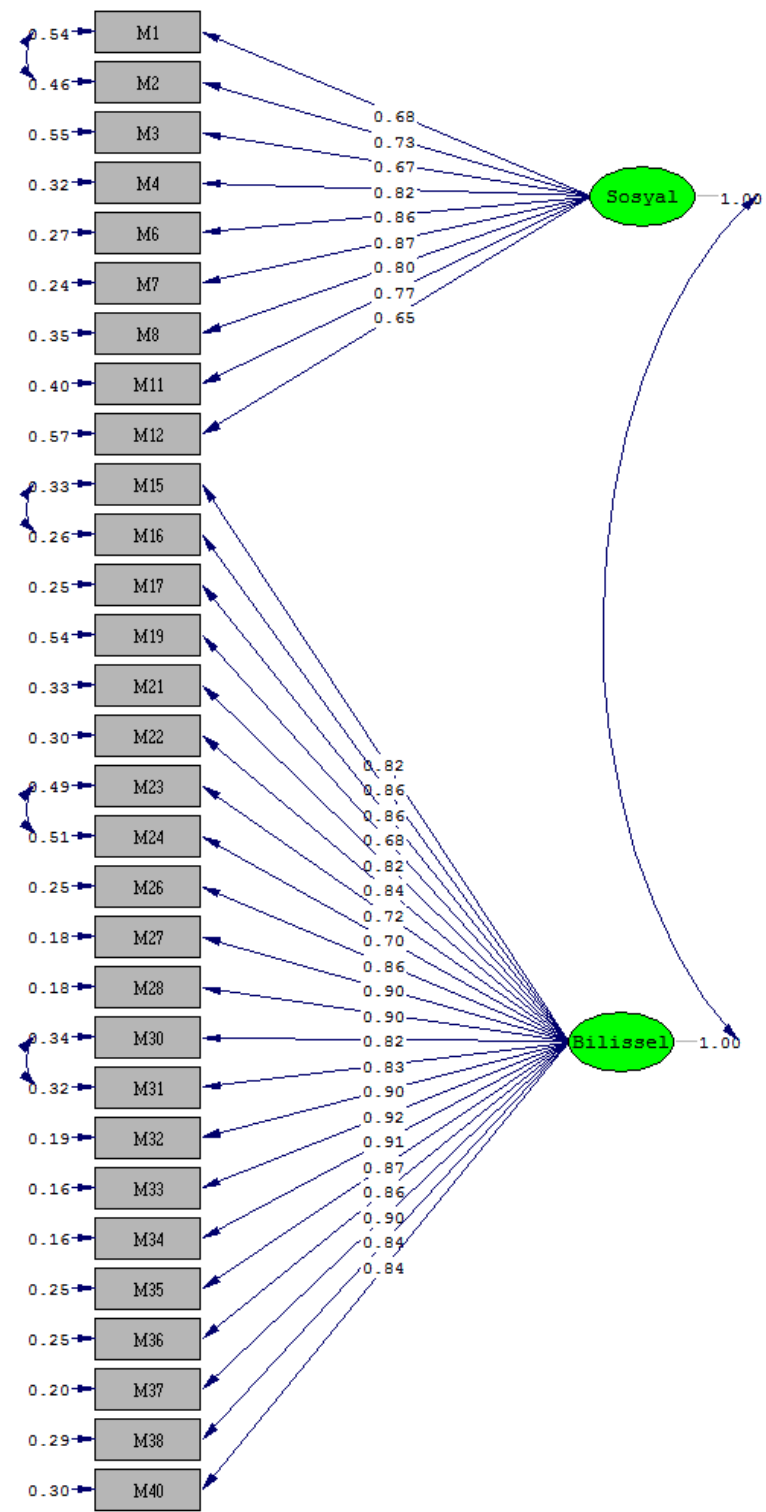

Şekil 2. Doğrulayıcı Faktör Analizi Sonuçları

Şekil 2'de maddelerin faktör yüklerinin, Sosyal boyut için 0.65 ile 0.87 arasında ve Bilişsel boyut için, 0.68 ile 0.90 arasında değiştiği görülmektedir. 


\section{Dinleme Becerisi Ölçeğinin Güvenirliğine İlişkin Bulgular}

Ölçeğin güvenirliğini belirlemede çeşitli yöntemler mevcut olup bu çalışmada uygulamanın bir kez yapılabilmesinden dolayı, ölçeğin iç tutarlılığını belirlemeye yönelik kestirimler yapılmıştır. Ölçeğin iç tutarlılık güvenirliğini belirlemek amacıyla hesaplanan Cronbach Alfa katsayısı, 0.94 olarak bulunmuştur. Bu bulguya göre, bireyler arasındaki değişimin \%94'ü, ölçülen nitelikle ilgili gerçek değişikliği, \%6'sının ise, tesadüfî hatalara âit olduğunu ifade etmektedir (Özgüven, 2014). Elde edilen bu değerin 1'e yakın olması, ölçeğin yüksek derecede güvenilir olduğunu göstermektedir.

\section{Sonuçlar}

$\mathrm{Bu}$ çalışmanın amacı, okul öncesi dönem çocukları için dinleme becerilerinin belirlenmesinde ve değerlendirilmesinde kullanılabilecek, geçerli ve güvenilir ölçme aracının geliştirilmesidir. $\mathrm{Bu}$ amacı gerçekleştirmek için geliştirilen ölçeğin, sosyal ve bilişsel olmak üzere iki boyuttan oluştuğu görülmüştür. Bu boyutlardan sosyal boyut 9 , bilişsel boyut ise 21 maddeden oluşmaktadır. Dinleme becerilerini değerlendirmek için geliştirilen farklı ölçek çalışmalarında da bu becerilerin benzer boyutlar altında toplandığı görülmektedir. Cooper ve Husband (1993) tarafından oluşturulan ölçekte de iki faktörlü bir yapı ortaya çıkmış ve bu boyutların, dinlemenin bilişsel ve sosyal içeriğine yoğunlaştığ1 görülmüştür. Çalışmada, bilişsel boyutun mesajın anlaşıld1ğının doğrulanması, sosyal boyutun ise, dikkat uyum davranışı, konuşmacıya ilgiyi vermenin doğrulanması maddelerini içerdiği vurgulanmıştır. Cooper, Seibold ve Suchner (1997) tarafından yapılan ça- 
lışmada ise, tek faktörlü bir yapı oluştuğu görülmüş; bu faktörde iletişim hedefleri olmaksızın dinlemenin kavrama boyutuyla ele alındığ görülmüştür.

Alanyazında, çocukların dinleme ile ilgili becerilerini belirleyebilmek için yapılan çalışmalarda âilelerden, öğretmenlerden ve çocuklardan, dinleme becerileri ile ilişkili olduğunu düşündükleri davranışları belirtmelerinin istendiği görülmüştür. Bu çalışmalar sonucunda, dinleme becerileriyle ilgili olduğu belirlenen boyutların uyum ve itaat davranışları, sosyal uygunluk sergileme, dikkat, soru sorma, anlamaya çalışma gibi kategorilere ayrıldığı belirlenmiştir (McDevitt, 1990, 1993; McDevitt, Spivey, Sheehan, Lennon ve Story, 1990). Bu alt boyutlar incelendiğinde, dinlemenin bu çalışma kapsamında ulaşılan boyutlara benzer şekilde kategorize edilebileceği söylenebilir.

Sonuç olarak çalışma kapsamında, okul öncesi dönem çocuklarının dinleme becerilerini değerlendirmeye yönelik geliştirilen ölçek, alanyazındaki kavramsal çerçeve ile örtüşmektedir. Bu durum, bulgular kısmında ayrıntılı olarak sunulan geçerlik ve güvenilirlik kanıtları ile de desteklenmektedir. Diğer bir ifadeyle, yapılan çalışma, geliştirilen ölçeğin dinleme becerilerini değerlendirmede, uygun niteliklere sahip olduğunu göstermektedir.

Türkiye'de, okul öncesi dönem çocuklarının dinleme becerileri ile ilgili yeterli seviyede çalışmanın yapılmamış olması gerçeğinden hareketle, bu araştırma kapsamında geliştirilen ölçeğin daha geniş örneklemlerde uygulanarak dinleme becerileri ile ilgili alanyazına kat- 
kıda bulunmaları önerilebilir. Dinleme becerileri okul öncesi dönemde, öğretmenler tarafindan daha çok gözlem yoluyla belirlenebilen bir beceri iken, standart bir ölçme aracı olarak bu ölçeğin kullanılması, daha objektif sonuçlar sunması ile birlikte, tekrarlı ölçümlerde öğrencinin dinleme becerileri bakımından ilerleme düzeyi ortaya konulabilir. Diğer bir anlatımla, ilk yapılan ölçümde, yetersiz olduğu belirlenen bir becerinin, daha sonra gelişip gelişmediğinin takibinde kullanılan standart bir ölçme aracının varlığı önem taşımaktadır.

Okul öncesi eğitimin amaçlarından biri de çocukları temel eğitim seviyesine hazırlamaktır. Temel eğitim düzeyinde kazandırılması plânlanan hedef davranışlara ulaşmada, çocuğun sâhip olduğu dinleme becerileri, önemli bir rol oynamaktadır. Bu açıdan, öğrencilerin dinleme becerilerinin belirlenmesi ve değerlendirilmesi, önemli görülmektedir. Araştırma kapsamında, erken çocukluk döneminde dinleme becerilerinin belirlenmesi ve değerlendirilmesi için geliştirilen ölçek, çocukların dinleme becerilerinde görülen eksikliklerin belirlenmesine ve değerlendirilmesine katkı sağlayabilecektir. Bu durum da ilerleyen dönemde, çocuğun eğitsel hedeflere ulaşmasında belirleyici olabilecektir.

\section{Kaynakça}

Balc1, A. (2006). Sosyal bilimlerde araştırma: yöntem, teknik ve ilkeler (6. bask1). Ankara: Pegem Akademi Yayınevi.

Baykul, Y. (2000). Eğitimde ve psikolojide ölçme: klasik test teorisi ve uygulaması. Ankara: ÖSYM Yayınları. 
Büyüköztürk, Ş. (2011). Sosyal bilimler için veri analizi el kitabı (13. bask1). Ankara: Pegem Akademi Yayınevi.

Calp, M. (2005). Özel öğretim alanı olarak Türkçe ögretimi. Konya: Eğitim Kitabevi.

Coakley, C. G., Halone, K. K. ve Wolvin, A. D. (1996). Perceptions of listening ability across the life span: Implications for understanding listening competency. International Journal of Listening, 10, 21-48.

Cooper, L. O. ve Husband, R. L. (1993). Developing a model of organizational listening competency. Journal of the International Listening Association, 7, 6-34.

Cooper, L. O. (1997). Listening competency in the workplace: A model for training. Business Communication Ouarteriy. 60(4), 75-84.

Cooper, L. O., Seibold, D. ve Suchner, R. (1997). Listening in organizations: An analysis of error structures in models of listening competency. Communication Research Reports, 14, 312-320.

Cooper, L. O. ve Buchanan, T. (2010). Listening competency on campus: A psychometric analysis of student listening. International Journal of Listening, 24(3), 141-163.

Crosskey, L. ve Vance, M. (2011). Training teachers to support pupils' listening in class: An evaluation using pupil questionnaires. Child Language Teaching and Therapy, 27(2), 165-182.

Çokluk, Ö., Şekercioğlu, G. ve Büyüköztürk, Ş. (2010). Sosyal bilimler için çok değişkenli istatistik SPSS ve LISREL uygulamaları (1. bask1). Ankara: PegemA Akademi Yayınevi. 
Doğan, Y. (2007). Illköğretim ikinci kademede dil becerisi olarak dinlemeyi geliştirme çalışmaları. Yayınlanmamış doktora tezi, Gazi Üniversitesi Eğitim Bilimleri Enstitüsü.

Doğan, Y. (2008). İlköğretim 7 sinıf öğrencilerinin dinleme becerisini geliştirmede etkinlik temelli çalışmaların etkililiği. Türk Ĕ̆itim Bilimleri Dergisi, 6(2), 261-286.

Doğan, Y. (2010). Dinleme becerisini geliştirmede etkinliklerden yararlanma. $T \ddot{U} B A R, 27,263-274$.

Erkuş, A. (2012). Psikolojide ölçme ve ölçek geliştirme I: Temel kavramlar ve işlemler. Ankara: Pegem Akademi Yayınevi.

Estrem, T. L. (2005). Relational and physical aggression among preschoolers: The effect of language skills and gender. Early Education and Development, 16(2), 207-231.

Florit, E., Roch, M., Altoe'G. ve Levorato, M. C. (2009). Listening comprehension in preschoolers: The role of memory. British Journal of Developmental Psychology, 27, 935-951

Florit, E., Roch, M., Altoe`G. ve Levorato, M. C. (2011). Listening text comprehension of explicit and implicit information in preschoolers: the role of verbal and inferential skills. Discourse Processes, 48(2), 119-138.

Halone, K. K. ve Pecchioni, L. L. (2001). Relational listening: A grounded theoretical model. Communication Reports, 14(1), 59-71.

Halone, K. K., Wolvin, A. D. ve Coakley, C. G. (1997). Accounts of effective listening across the life-span: Expectations and experiences associated with competent listening practices. International Journal of Listening, 11, 15-38. 
Imhof, M. ve Janusik, L. A. (2006). Development and validation of the Imhof-Janusik listening concepts inventory to measure listening conceptualization differences between cultures. Journal of Intercultural Communication Research, 35(2), 79-98

Jalongo, M. R. (2010). Listening in early childhood: An interdisciplinary review of the literature. International Journal of Listening, 24(1), 1-18.

Janusik, L. (2002). Teaching listening: What do we do? What should we do? International Journal of Listening, 16(5), 5-39

Jones, D. (2007). Speaking, listening, planning and assessing: The teacher's role in developing metacognitive awareness. Early Child Development and Care, 177, 569-579.

Kan, A. (2007). Öğretmen adaylarının eğitme-öğretme özyetkinliğine yönelik ölçek geliştirme ve eğitme-öğretme özyetkinlikleri aç1sından değerlendirilmesi (Mersin Üniversitesi Örneği). Mersin Üniversitesi Ĕ̈itim Fakültesi Dergisi, 3(1), 35-50.

Kline, R. B. (2005). Principles and practice of structural equation modeling. NewYork: The Guilford Press.

Lamm, O., Share, D. L, Shatil, E. ve Epstein, R. S. (1999). Kindergarten dichotic listening as a predictor of first-grade reading achievement. DYSLEXIA, 5, 138-154.

Machado, J. M. (2010). Early childhood experiences in language arts early literacy. Wadsworth: Cengage Learning.

McDevitt, T. M. (1990). Mothers' and children's beliefs about listening. Child Study Journal, 20(2), 105-129. 
McDevitt, T. M. (1993). Beliefs about listening: Perspectives of mothers and early-childhood teachers. Child Study Journal. 23(3), 153-173.

McDevitt, T. M., Spivey, N., Sheehan, E. P. Lennon, R. ve Story, R. (1990). Children's beliefs about listening: Is it enough to be still and quiet? Child Development, 61, 713-721.

Mickelson, W. T. ve Welch, S. A. (2012). Factor analytic validation of the ford, wolvin, and chung listening competence scale. International Journal of Listening, 26(1), 29-39.

Milli Eğitim Bakanlığı Okul Öncesi Eğitim Genel Müdürlüğü. (2006). Okul öncesi ĕgitim program (36-72 aylık çocuklar için). Ankara: Milli Eğitim Bakanlığı, Devlet Kitapları Müdürlüğü.

Milli Eğitim Bakanlığı Okul Öncesi Eğitim Genel Müdürlüğü. (2012). Okul öncesi eğitim program (36-72 aylık çocuklar için). Ankara: Milli Eğitim Bakanlığg, Devlet Kitapları Müdürlüğü.

Öner, N. (1997). Türkiye'de kullantlan psikolojik testler. İstanbul: Boğaziçi Üniversitesi Yayınları.

Özbay, M. (2005). Dinleme ĕ̆itimi. Ankara: Akçă̆ Yayınları.

Özgüven, İ. E. (2014). Psikolojik Testler, Ankara: Nobel Akademi Yayıncılık.

Robinshaw, H. (2007). Acquisition of hearing, listening and speech skills by and during key stage 1. Early Child Development and Care, 177(6/7), 661-678. 
Rubin, R. L., Flagg-William, J. B., Aquino-Russell, C. E. ve Lushington, T. P. (2011). Classroom acoustics classroom listening environment school-age children hearing screening sound field amplification. Canadian Journal of Speech-Language Pathology and Audiology, 35(4), 344-359.

Schermelleh-Engel, K. ve Moosbrugger, H. (2003). Evaluating the fit of structural equation models: Tests of significance and descriptive goodness-of-fit measures. Methods of Psychological Research Online, 8(2), 23-74.

Smith, L. (2006). What effect does listening to individual children have on their learning?, Pastoral care in education: an international journal of personal. Social and Emotional Development, 24(4), 31-38.

Sümer, N. (2000). Yapısal eşitlik modelleri: Temel kavramlar ve örnek uygulamalar. Türk Psikoloji Yazıları, 3(6), 49-74.

Swain, K., Harrington, J. M. ve Friehe, M. (2004). Teaching listening strategies in the inclusive classroom. Intervention in School and Clinic, 40, 48-55.

Şeker, H. ve Gençdoğan, B. (2006). Eğitimde ve psikolojide ölçme aracı geliştirme. Ankara: Nobel Yayınevi.

Şimşek, Ö. F. (2007). Yapısal eşitlik modellemesine giriş (Temel ilkeler ve LISREL uygulamalart). Ankara: Ekinoks Basım Yayın ve Dağıtım.

Tatlıdil, H. (2002). Uygulamalı çok değişkenli istatistiksel analiz. Ankara: Akademi Matbaası.

Tavşanc1l, E. (2002). Tutumların ölçülmesi ve SPSS ile veri analizi. Ankara: Nobel Yayınları. 
Visu-Petra, L., Cheie, L. ve Benga, O. (2008). Short-term memory performance and metamemory judgments in preschool and early school-age children: A quantitative and qualitative analysis. Cognitive, Creier, Comportament/Cognition, Brain, Behavior, 12(1), 71-101.

Yılmaz, İ. (2007). Türkçe eğitiminde dinleme becerisini geliştirmeye yönelik önerilen etkinliklerin değerlendirilmesi. Yayınlanmamış yüksek lisans tezi, Niğde Üniversitesi Sosyal Bilimler Enstitüsü. 